\title{
DRUMLIN FORMATION RELATED TO INVERTED MELT-WATER EROSIONAL MARKS
}

\author{
By JOHN SHAw \\ (Department of Geography, Queen's University, Kingston, Ontario K7L 3N6, Canada)
}

\begin{abstract}
Drumlin forms are described from maps and air photographs of a part of the Athabasca Plains, northern Saskatchewan. Three major forms, spindle, parabolic and transverse asymmetrical are recognized. These forms, which may show superimposed minor elements, depart from classical descriptions of drumlins, but are similar to moulds of erosional marks created by separated fluid flows. Assemblages of drumlins also show characteristics similar to those of erosional marks. The form analogy between drumlins and moulds of erosional marks is carried to a conclusion that drumlins may be formed by the infilling of erosional marks created on the under-side of glaciers by separated, subglacial melt-water flows. Estimates of specific discharge are obtained by means of an expected range of Reynolds number. Geomorphological evidence is given for large-scale erosion by subglacial melt water. A discussion of the sedimentology, stratigraphy, and deformational structure of the interiors of drumlins shows that they may be explained by the erosional-mark hypothesis. This paper emphasizes the importance of melt water as a geomorphic agent and may have broad implications for ice-sheet dynamics and profiles, rates of deglaciation, and the occurrence of bedrock thrusting by ice.
\end{abstract}

RÉsumÉ. Formation des drumlins reliee à des traces inversées d'érosion par les eaux de fusion. Des formes de drumlins sont décrites à partir de cartes et de photographies aériennes d'une partie des Athabasca Plains, au nord du Saskatchewan. On en a reconnu trois principales formes, en fuseau, paraboliques et transversales asymétriques. Ces formes qui peuvent présenter en surimposition d'autres éléments mineurs, se distinguent des descriptions classiques de drumlins, mais ressemblent à des matrices de traces d'érosion créees par des écoulements fluides séparés.

Des ensembles de drumlins montrent aussi des caractéristiques semblables à celles de traces d'érosion. L'analogie de formes entre les drumlins et des matrices de trous d'érosion conduit à la conclusion que les drumlins peuvent avoir été formés par le remplissage de traces d'érosion creès à la face inférieure des glaciers par des écoulements séparés d'eau de fonte sous-glaciaire. Des estimations des débits spécifiques en sont déduites grâce à une évaluation de l'ordre de grandeur du nombre de Reynolds. Des preuves géomorphologiques sont fournies d'une érosion à grande échelle par les eaux de fusion sous-glaciaires. Une discussion sur la sédimentologie, la stratigraphie et les structures de déformation de l'intérieur des drumlins montrent qu'ils peuvent être expliqués par l'hypothèse de traces d'érosion. Cet article souligne l'importance des eaux de fusion comme agent geomorphologique et peut comporter de plus vastes implications pour la dynamique et le profil des calottes glaciaires, les vitesses de déglaciation et la présence de blocs de poussée glaciaire.

Zusammenfassung. Drumlinbildung in Beziehung zu invertierten Mustern der Schmelzwassererosion. Mit Hilfe von Karten und Luftbildern eines Teiles der Athabasca Plains, Nord-Saskatchewan, werden Drumlinformen beschrieben. Drei Gruppen von Formen, nämlich spindelartige, parabolische und in Querrichtung asymmetrische lassen sich erkennen. Diese Formen, die von kleineren Elementen überlagert sein können, gehen von klassischen Drumlinbeschreibungen aus, ähneln jedoch den Abdrücken von Erosionsmustern, die durch den Fluss in getrennten Gerinnen entstanden sind. Scharen von Drumlins zeigen ebenfalls Charakteristiken, die Erosionsmustern gleichen. Die Formenanalogie zwischen Drumlins und Abdrücken von Erosionsmustern führt zu der Folgerung, dass Drumlins durch die Auffüllung von Erosions-mustern gebildet wurden, die an der Unterseite von Gletschern /durch getrennte, subglaziale Schmelzwasserströme entstanden. Schätzungen des spezifischen Abflusses lassen sich mit Hilfe des Erwartungsbereiches der Reynolds-Zahl gewinnen. Geomophologische Beweise für eine gross angelegte Erosion liefert das subglaziale Schmelzwasser. Eine Untersuchung der Sedimentierung, Stratigraphie und Deformationsstruktur im Innern von Drumlins zeigt, dass sie sich mit der Hypothese eines Erosionsmusters erklären lassen. Die Arbeit betont die Bedeutung von Schmelzwasser als formenbildendes Agens und könnte von grosser Tragweite für Probleme wie Profile und Dynamik von Eisschilden. Eisrückgangsraten und Auftreten von Rundhöckerlandschaften durch Eis sein. 


\section{INTRODUCTION}

The striking feature of drumlins and other so-called ice-moulded landforms is their apparently streamlined appearance. Chorley (1959) wrote specifically on the shape of drumlins and emphasized their plan form, which he showed could be fitted by lemniscate loops. Such loops also fit airfoils designed to prevent separation of flow around them, and, on the basis of this form relationship, Chorley argued that the lemniscate form was of genetic significance. It is widely accepted that the streamlined form of drumlins is moulded by active ice flowing around an upstanding obstacle at or near the glacier/bed interface. Menzies (1979, p. 315), in developing this concept of streamlining, describes the classical drumlin as showing a blunter end pointing up-ice and a gentler-sloping, pointed end facing down-ice. Descriptions of typical drumlins are widespread and large fields of such forms are illustrated in maps (see for example Glückert 1973).

Some drumlins on the Athabasca Plains of northern Saskatchewan, Canada, depart dramatically from the classical descriptions. This raises a question of definition as some might argue that features differing from the classical form should not be called drumlins at all. From what follows, the various forms, including classical drumlins, appear to be closely related. So I prefer to follow the practice of earlier researchers of these features and call them all drumlins (Sproule, 1939; Acton and others, 1960; Bayrock, 1972).

One set of drumlins shows a pointed stoss end and a parabolic outline in plan view such that maximum width occurs close to the down-ice margin. They are highest closer to the stoss end and taper gently towards the lee margin which is poorly defined as it merges gradually with the surrounding ground. This set is referred to as parabolic forms. The parabolic forms occur in close association with classical, though fairly narrow types that are called spindle forms. A third type is broader than it is long in that it shows greater extent transverse to the direction of former ice flow than parallel to it. In plan view these broad forms are usually asymmetrical about an axis drawn parallel to the former flow direction and so are named transverse asymmetrical forms. Unlike the smooth, regular transverse profile described by Chorley (1959), the drumlins to be described show a variety of superimposed forms. The morphology of the drumlins on the Athabasca Plains will be described from air photographs and maps.

Drumlin forms show striking similarity with those of casts of erosional marks associated with turbidites and karst solution features despite several orders of magnitude difference in scale. This morphological similitude can be applied even to minor, superimposed form elements. An argument is developed to suggest that drumlin form may be related to erosional marks produced on glacier beds by subglacial melt-water flows. Explanations of how the resulting cavities might be infilled are given and relationships between the Saskatchewan drumlins, large fluvially eroded channels, and eskers illustrate the important landforming role of subglacial melt water. A discussion on stratified material within drumlins and its deformation shows that the erosionalmark hypothesis explains many characteristics which are otherwise problematical.

\section{The Athabasca Plains, Saskatchewan}

Although the discussion of form in this work is based on air-photograph and map interpretation, there follows a brief description of the physiography and geology of the Athabasca Plains upon which the drumlins occur. Acton and others (1960) described the Athabasca Plains as an area of undulating to strongly rolling country located in Saskatchewan 
south and south-east of Lake Athabasca (Fig. 1). Elevation ranges between 180 and $485 \mathrm{~m}$ a.s.l. and the Plains correspond to the area of outcrop of the Pre-Cambrian Athabasca Formation which consists mainly of quartzitic sandstone (Blake, 1956). This Pre-Cambrian sandstone looks hard but when broken is surprisingly friable (Blake, 1956, p. 7). The sandstone source materials result in very sandy surficial deposits (Acton and others, 1960). Eskers and drumlins, both of which dominantly contain sand, are prominent and occur as part of a huge field extending some $500 \mathrm{~km}$ back to a centre in the Keewatin District west of Hudson Bay (Prest and others, 1968, fig. 1.). It is of interest to note, in the context of this paper, that Sproule (1939) suggested that drumlins in the vicinity of Cree Lake on the Athabasca Plains resembled migrating bed-forms. Wilson (1938) had made the same suggestion for drumlins in Nova Scotia. Ice flow was generally from north-east towards the south-west and, although end moraines or other icemarginal forms are rare in the area of study, a prominent moraine, the Cree Moraine, is found to the south-west (Christiansen, 1979). Christiansen (1979) places the time of formation of the Cree Moraine at about 10000 years B.P. The landforms to be discussed in detail are found in the area of the Livingstone Lake, Saskatchewan (NTS 1:250 000 map sheet $74 \mathrm{~J}$, lat. $58-59^{\circ} \mathrm{N}$., long. $106-108^{\circ}$ W.).

\section{Drumlin forms on the Athabasca Plains}

As already indicated, the forms of some drumlins on the Athabasca Plains of northern

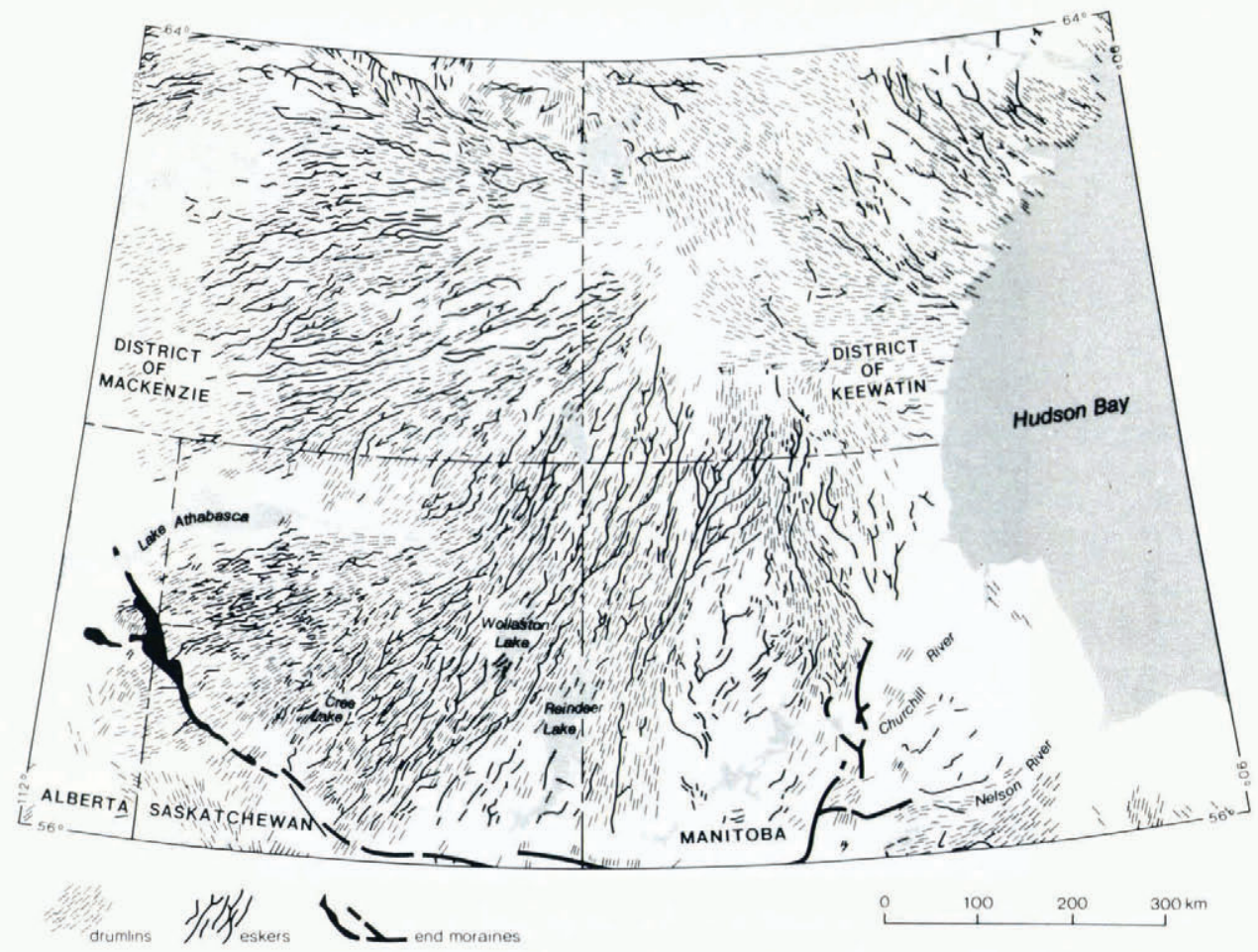

Fig. 1. Systems of drumlins and eskers related to the Athabasca Plains drumlins (after Prest and others, 1968). 


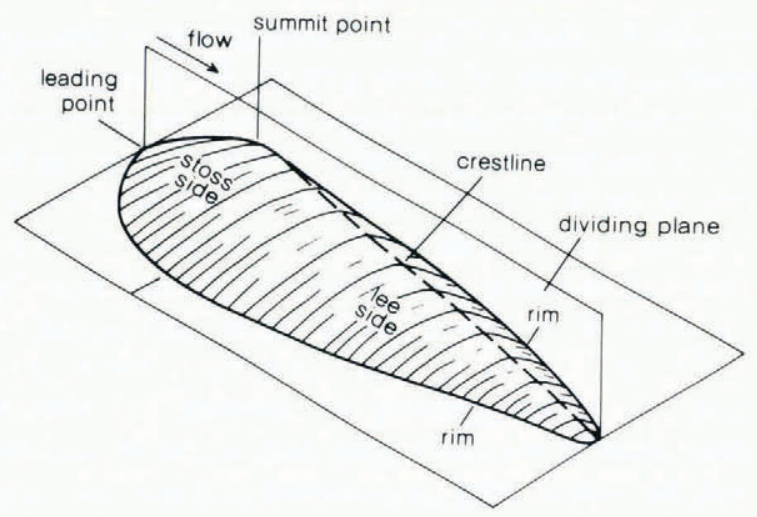

Fig. 2. The classical drumlin.

Saskatchewan differ considerably from that of the classical drumlin illustrated in Figure 2. The classical form has a rim with a lemniscate loop plan form and is symmetrical about a dividing plane defined as the vertical plane passing through the leading point and drawn parallel to the assumed flow direction. The leading point is the furthest up-flow extent of the rim. The stoss slope is the slope which faces up-flow and the lee slope faces down-flow. The crest-line joins the highest points and in the classical drumlin is everywhere parallel to the assumed flow direction.

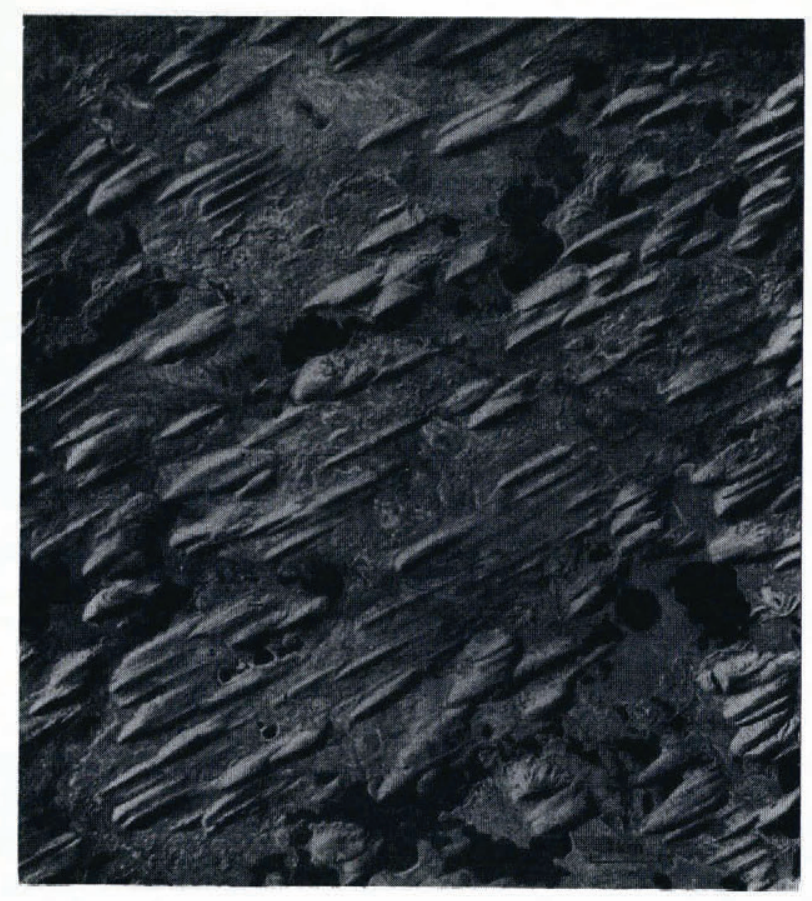

Fig. 3. Air photograph of an area dominated by isolate spindle and parabolic drumlins together with conjugate clusters. General location Livingstone Lake, Saskatchewan 1:50000 NTS Map Sheet $74 \mathrm{~J} / 11$, lat. $58^{\circ} 30^{\prime} \mathrm{N}$., long. $107^{\circ} 30^{\prime}$ W. Airphoto designation A 14509-5. Courtesy of the National Air Photo Library, Ottawa. 
The summit point is the highest point on a drumlin and is found closer to the proximal (up-ice) than the distal (down-ice) margin of the form such that the stoss slope is steep and the lee slope relatively gentle.

Two air photographs illustrate the dominant drumlin forms, spindle, parabolic, and transverse asymmetrical, on the Athabasca Plains (Figs 3 and 4). Each figure contains an assemblage of similar forms but the two assemblages are markedly different. The forms of Figure 3 are dominantly longitudinal, that is elongate in the former flow direction, whereas those in Figure 4 are transverse in that they are much more extensive in a direction at right-angles to the former flow. The transverse forms also show minor ridges and furrows arranged longitudinally and, in plan view, are highly asymmetrical about their dividing planes. Rim outlines drawn directly from air photographs illustrate the three dominant isolate forms (Fig. 5). An isolate form is one which is not in contact with other forms; forms in contact are said to be conjugate.

Spindle forms are relatively long and narrow and are usually symmetrical about their dividing plane. Their rims form closed loops pointed at both ends. Spindle forms do not normally have minor, superimposed elements.

Parabolic forms are generally broader than spindle forms and the rims do not close in the down-flow direction. The rims are pointed in the up-flow direction and width increases downflow, although there may be a slight departure from parabolic form with a slight decrease in width in the distal zone. Parabolic forms may be symmetrical or asymmetrical about their

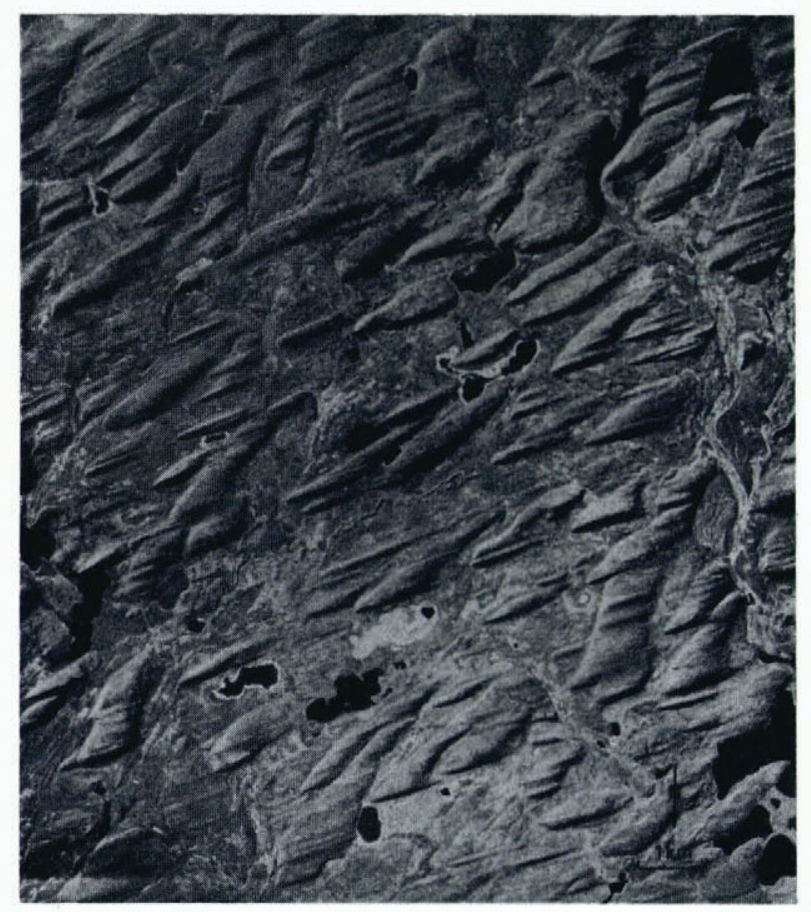

Fig. 4. Air photograph of an area dominated by transverse asymmetrical drumlins. Note the common occurrence of minor troughs and ridges superimposed on the major landforms. General location Rumpel Lake, Saskatchewan 1:50 000 NTS Map Sheet $74 \mathrm{~J} / 7$, lat. $58^{\circ} 28^{\prime}$ N., long. $106^{\circ} 30^{\prime}$ W. Airphoto designation A 14509-77. Courtesy of the National Air Photo Library, Ottawa. 


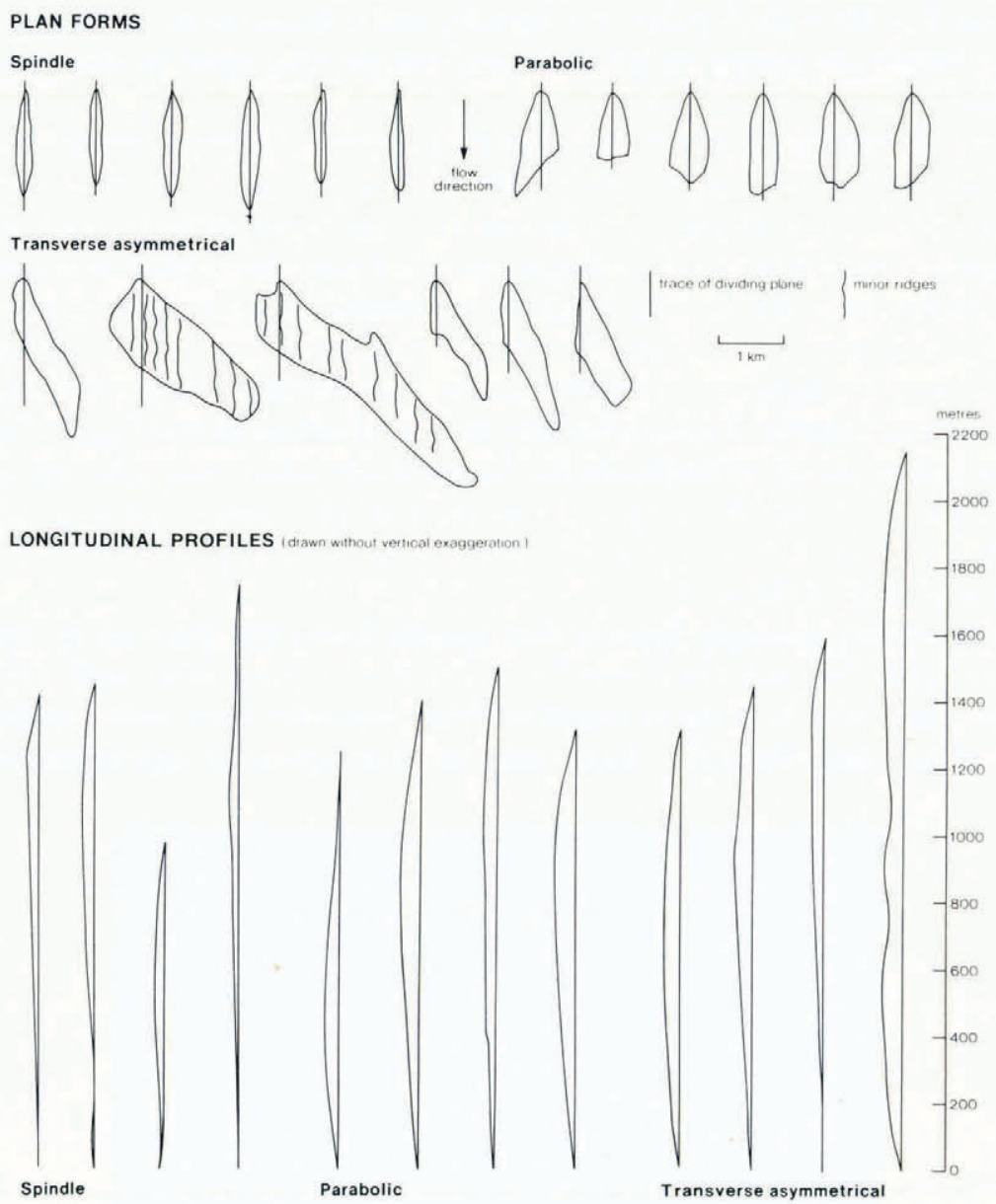

TRANSVERSE PROFILE Transverse asymmetrical

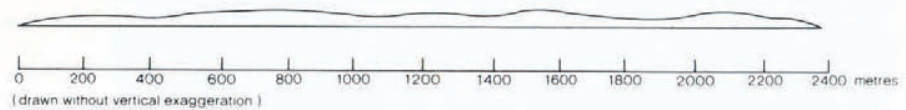

Fig. 5. Drumlin outlines drawn directly from air photographs illustrating spindle, parabolic, and transverse asymmetrical forms. Profiles constructed from the Livingstone Lake $74 \mathrm{~J} / 11$ and Rumpel Lake $74 \mathrm{~J} / 7$ 1:50 000 NTS Map Sheet with a contour interval of $10 \mathrm{~m}$. The profiles are drawn without vertical exaggeration.

dividing planes. They commonly show ridges extending down flow in the form of horns or arms that embrace a central trough (Fig. 6). In other, more simple cases the ridges and trough are absent and transverse profiles are relatively regular. In yet other cases only one arm or horn appears. Where parabolic forms are relatively broad, they commonly have superimposed minor ridges and furrows.

Transverse asymmetrical forms are long in the direction transverse to flow and highly 


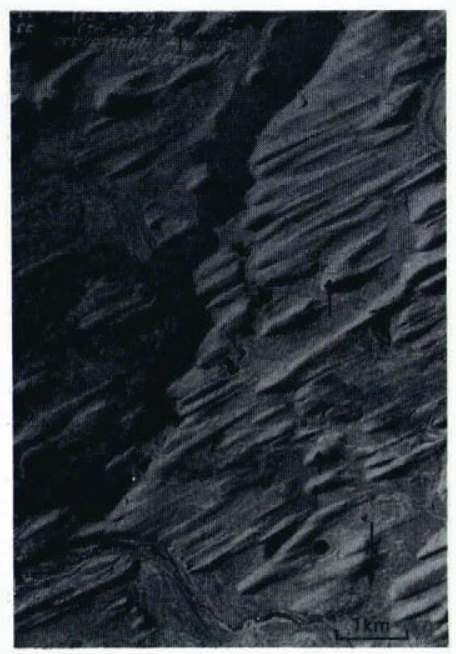

Fig. 6. Parabolic drumlins with extending horns or arms and a central trough (marked by arrows). Note the large number of drumlins located directly west of the long trough eroded into bedrock and occupied by the ribbon lake. General location Livingstone Lake Saskatchewan 1:50 000 NTS Map Sheet. Airphoto designation A14509-2. Courtesy of the National Air Photo Library, Ottawa.

asymmetrical about their dividing planes. These forms generally carry minor, superimposed ridges and troughs (Fig. 4).

Isolate features may be over $80 \mathrm{~m}$ in height and $2 \mathrm{~km}$ in length. Profiles drawn parallel to the dividing plane are distinctly asymmetrical with a steep stoss and gentle lee face (Fig. 5). Minor ridges and troughs on the transverse asymmetrical forms appear on transverse profiles drawn from 1:50000 scale maps with a contour interval of $10 \mathrm{~m}$ (Fig. 5). Other minor features appear on air photographs. Spindle forms are generally without minor elements. Minor ridges and troughs often occur marginal to parabolic forms and appear to skirt around them. Idealized sketches of the three drumlin types are presented in Figure 7.

Conjugate drumlins that appear in clusters are also present. Similar clustering and superimposition were noted by Rose and Letzer (1977) who termed these clustered forms megadrumlins. Figure 6 illustrates that a number of drumlins begin at the down-flow margin of the long trough, cut into bedrock, just left of centre on the figure. This major surface form has clearly been important in fixing the positions of these drumlins.

Not only are forms similar over limited areas, but also the nature of the asymmetry is the same in fields of transverse asymmetrical drumlins. This is illustrated by Figure 4 in which the leading point and dividing plane of each asymmetric feature are much closer to the northern than the southern rim. The similarity of form and asymmetry over broad areas favours an explanation of these features in which conditions in the formative flow were organized according to some fundamental, but yet undiscovered, principles.

\section{DRUMLINS AND EROSIONAL MARKS}

A variety of erosional marks occurring in nature are related to removal of material by solution, corrasion, fluid stressing of weak materials, cavitation, and ablation. Allen (1971) made an outstanding, although preliminary, theoretical and experimental study of the mechanics of formation of these marks. A major conclusion of his work was that although the physical and chemical mechanisms producing erosional marks are different, the forms are indistinguishable 


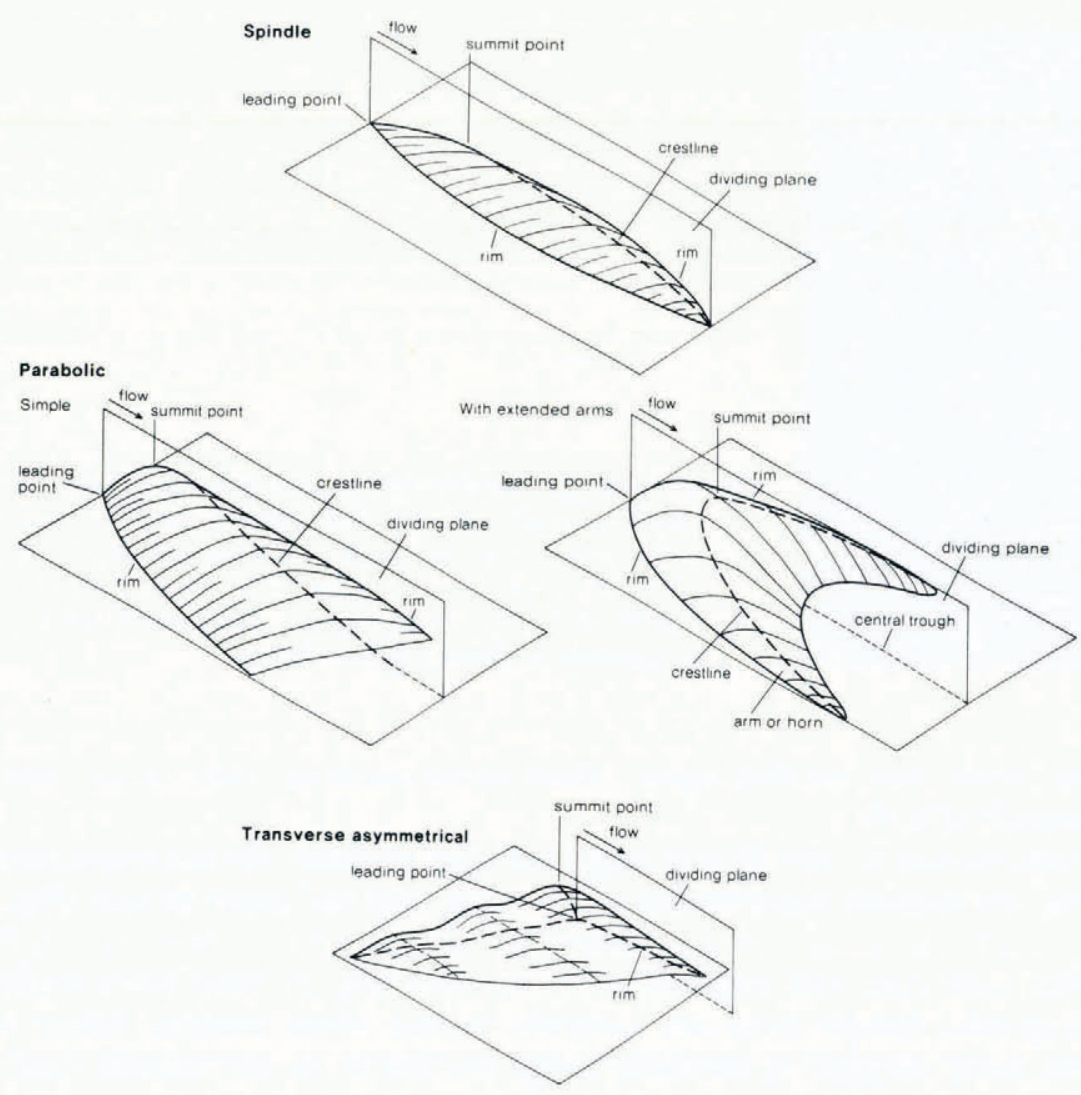

Fig. 7. Idealized sketches of spindle, parabolic (with and without arms), and transverse asymmetrical drumlin forms. Turn the page upside down to visualize the drumlins as erosional marks.

one from another. The fundamental reason for this form similarity is that the eroding mechanisms occur in conjunction with separated fluid flows. Allen (1971, p. 169) concluded that, as the eroding processes are physically analogous and the erosional marks are dependent on separated flows, "It is a proper and inevitable consequence of the analogy that geometric similarities should exist between marks formed in different ways".

My initial reaction on viewing the air photographs of the Athabasca Plains drumlins was that the forms are more complex than is expected of drumlins and that their appearance was familiar. Following this intuition, examination of Dzulinski and Walton (1965, chapter 3) revealed an amazing similarity in form and assemblage of the obstacle scour moulds of their figure 60 (produced here as a drawing in Fig. 8A) and those in parts of Figure 3. Of course, the difference in linear scale is enormous, some five orders of magnitude. Further enquiry showed that other erosional marks, now appearing as mould casts at the base of turbidite beds, were similar in form to drumlins. Parabolic sole-mark casts (Fig. 8B produced from Dzulinski and Walton, 1965) are similar in form to parabolic drumlins even to the extent of mimicking the minor lateral furrows and ridges. There is aiso a trace of central troughs in some mould casts similar to those illustrated in Figure 6. Perhaps even more strikingly similar are the asymmetric flute moulds 

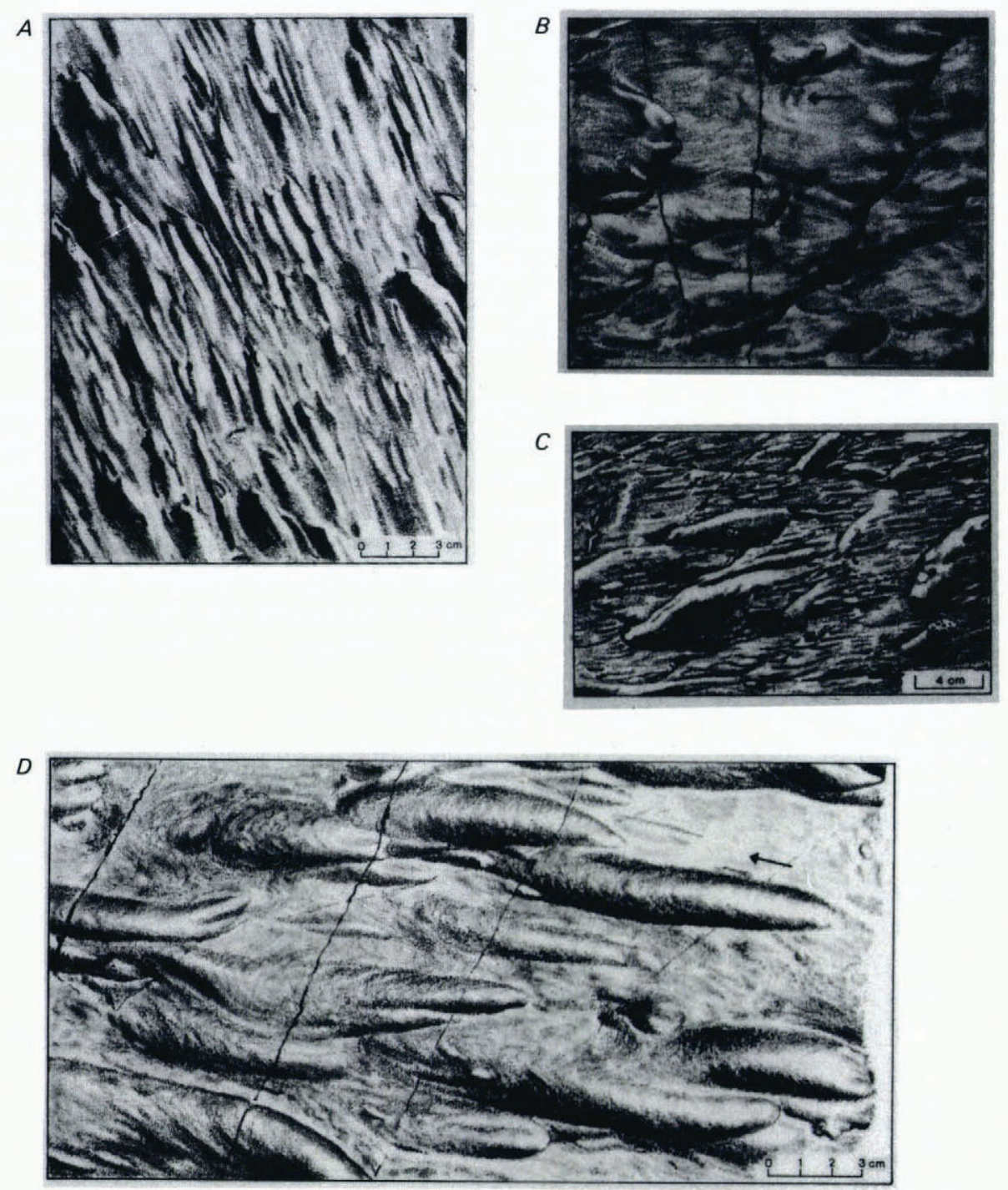

Fig. 8. Erosional marks associated with turbidites. A. Longitudinal obstacle-scour moulds cut behind small tools. B. Conical flute moulds. Note the similarities between these and the broad parabolic forms of Fig. 3 . C. Asymmetrical flute moulds merging into diagonal structures. Note the similarities between these and the transverse asymmetrical drumlins of Figure 4. D. Narrow parabolic and spindle forms of flute casts. A, B,C and $D$ were drawn from figs. 60, 26, 35 and 28, respectively, of Dzulinski and Walton, 1965.

merging into diagonal structures (Fig. 8C) and the transverse asymmetrical drumlins of Figure 4. In particular, the appearance of minor ridges and troughs is marked in both forms. Finally, spindle forms, although well illustrated in Figure 8A, are shown enlarged (Fig. 8D). These compare closely with the spindle forms shown in Figure 3 and drawn in Figure 5.

Erosional marks are commonly parabolic and show horns or arms extending down-flow. These forms are copiously illustrated by Allen (1971) and one such illustration is reproduced 
here (Fig. 9). The geometry of the moulds of such parabolic forms is closely similar to that of the parabolic forms of some drumlins (Figs 6 and 7). Allen (1971, fig. 57) also illustrates spindleshaped erosion marks similar to those of Figures 3 and 7.

The morphological analogy between drumlins and casts of erosional marks is thus seen to be strong. As with erosional marks, drumlins occur in assemblages, and a notable similarity is that a single form tends to dominate fields or parts of fields, so that for example longitudinal forms dominate the area of Figure 3 and transverse features dominate the area of Figure 4. Allen (1971, p. 168) expresses this concept with regard to turbidite erosion forms, "... one is struck in looking at turbidite flute and scour marks with the fact that marks on any one under-surface are quite different in shape, size and spatial arrangement from those preserved on nearby bedding surfaces in the same formation".

The Athabasca Plains drumlins occur in clustered heterogeneous assemblages. Transverse erosional marks also occur commonly in similar clustered assemblages (Allen, 1971, fig. 3). Allen's (1971, p. 176-77) description of this clustered assemblage for erosional marks, "conjugate marks separated by areas of smooth bed or bed with isolate marks", accurately describes the assemblage of Figure 3. However, the positions of some drumlins are evidently fixed by large-scale bed irregularities (Fig. 6). A similar arrangement applies to Sichelwannen, sublacial erosional marks in bedrock which often occur in transverse rows fixed in position by prior joints and factures (Allen, 1971, p. 183). Thus the assemblages of drumlins and their spatial patterns have much in common with those of erosional marks.

Following Allen's (1971) conclusion concerning the similarity of forms produced by separated flows, it is reasonable to propose that drumlins which show closely related forms and form assemblages are also related to separated flows. It should be noted that, although this argument is reasonable, there remains the possibility that all erosional forms produced by separated flows bear similarities but all forms which show this geometrical similarity were not produced by separated flows. Hence, some forms similar to erosional marks may be formed by flows without separation. However, given the coincidence of form and form assemblage between erosional marks and drumlins the analogy should be pursued.

As yet in this paper there has been no statement of how the drumlin form is created such that the analogy between drumlin form and erosional marks may be extended to a plausible
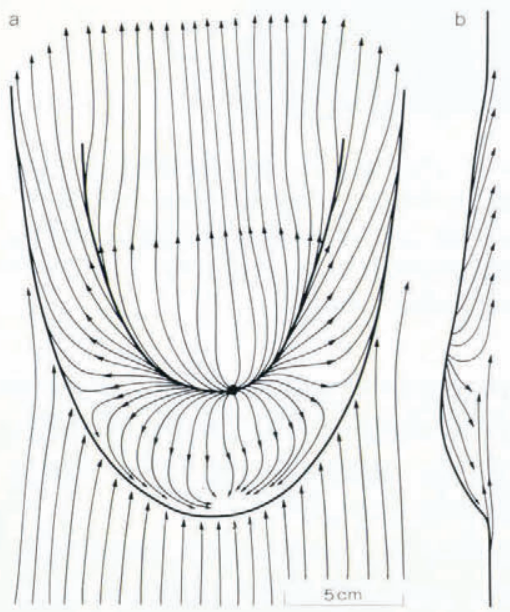

Fig. 9. Parabolic erosional mark with horns and a central ridge. Skin friction lines illustrate the separating flow close to the bed (after Allen, 1971, fig. 56). To visualize the erosional mark as a drumlin, turn the page upside down. 
environment of formation. The drumlins are obviously not erosional marks as such for they are upstanding features up to $80 \mathrm{~m}$ high. Consequently in pursuing our analogy, drumlins are casts of the original erosional marks just as sole marks are commonly displayed as casts on the underside of the turbidite beds. There can be no question of the land suface being overturned! So the erosional marks must have been eroded upwards into the under-side of an overriding glacier and were formed at the top of a confined flow in much the same way as erosional marks are formed by solution on cave roofs. Taking the analogy further it is assumed, given the subglacial environment, that the erosional marks were formed on the under-side of a glacier by subglacial melt water flowing with local separation. The mechanism of erosion is ablation caused by heat transfer from the flowing water to the ice. A schematic drawing of this general concept is presented (Fig. 10). Minor superimposed forms are related to smaller-scale separations than those producing the large marks (Allen, 1971).

If the analogy between drumlins and erosional marks is valid, then some direct comparisons may be made. If behavioural characteristics can be shown to be similar, then the analogy is extended beyond purely geometric considerations. Allen (1971) related parabolic erosional marks to unstable conditions under which they grow in amplitude for all time. Spindle-shaped marks, on the other hand, represent stable forms which may even become smaller in amplitude after an initial growth period. It is, therefore, expected that parabolic drumlins should be higher than spindle forms if they are related to erosional marks. Although height cannot be determined accurately from the topographic maps available, the minimum relief of a feature above its surroundings may be obtained by counting the number of enclosing contour lines $(n)$ for isolate features. The minimum relief is then $(n-11) \mathrm{I}$, where $I$ is the contour interval. This procedure was used for isolate spindle and parabolic forms appearing on air photograph A 14509-5 which appears here as Figure 3. Parabolic forms have a mean minimum relief of $54.2 \mathrm{~m}(n=21$, standard deviation $=13.6 \mathrm{~m}$ ) whereas spindle forms have a mean minimum relief of only $18.6 \mathrm{~m}$ $(n=14$, standard deviation $=6.6 \mathrm{~m})$. Although this is not a powerful test, the results are certainly in keeping with the analogy. For comparison, transverse asymmetrical drumlins (photograph A 14509-93) have a mean minimum relief of $36.7 \mathrm{~m}(n=18$, standard deviation $=8.4 \mathrm{~m})$. It may be that the spindle forms are lower as a consequence of their being narrower than the parabolic

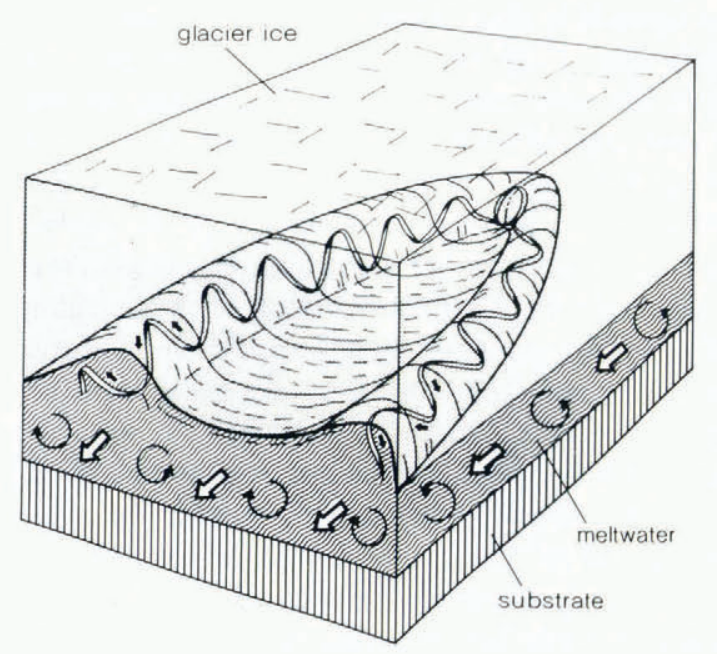

Fig. 10. Idealized environment and flow conditions for the production of an erosional mark on the underside of a glacier. 
forms, but this again suggests that the spindle forms represent features that did not grow as rapidly as parabolic forms, or may even be related to erosional marks that were being erased.

\section{SUBGLACIAL WATER FLOW: DISCHARGE ESTIMATES AND GEOMORPHOLOGICAL EVIDENCE}

It is difficult to estimate the duration and magnitude of the water flows required to produce erosional marks on the scale of drumlins. This is particularly the case because the hydraulics of even those erosional marks that can be produced in laboratories is very imperfectly understood. A guiding principle is that the flows should at least be turbulent and Allen (1971) gives a range of Reynolds numbers over which erosional marks are formed. If the Reynolds number is written as $q / \nu$, where $q$ is discharge per unit width, that is the product of flow depth and mean velocity, and $\nu$ is kinematic viscosity taken here for water at $0^{\circ} \mathrm{C}$, a range of specific discharges can be obtained directly from the range of Reynolds numbers, $2000<(R e)<32000$. The range of specific discharge obtained is $0.32 \mathrm{~m}^{3} \mathrm{~s}^{-1} \mathrm{~m}^{-1}$ to $4.0 \mathrm{~m}^{3} \mathrm{~s}^{-1} \mathrm{~m}^{-1}$. These discharges are two to three orders of magnitude greater than the specific discharge produced by melting of the area of the ice bed up-stream of the drumlins by geothermal heat, and also much greater than if melting produced by basal sliding is added (Wright, 1973). The specific discharges could reach the required levels as a result of sudden drainage of large sub- or englacial bodies of water, or if basal melt water from a large catchment were concentrated in relatively narrow "streams". Also, ablation at the ice surface may contribute to the discharge at the bed if there is a hydraulic connection between the surface and the bed. Ablation of the glacier bed during formation of the erosional marks adds considerably to the total volume of water discharged. But the contribution to specific discharge cannot be obtained without some estimate of the rate of ablation. This is a fundamental and difficult problem relating to the very formation of erosional marks.

The question of independent evidence for large discharges of subglacial waters can be answered with some confidence on geomorphological grounds. The drumlins of the Athabasca Plains are associated with spectacular eskers having lengths measured in tens of kilometres. The flows which produced these eskers occasionally climbed over drumlins and are represented at these localities by melt-water erosion channels aligned with esker segments on either side of the drumlin. For the water to flow uphill over the drumlin it must have been under hydrostatic pressure and thus the eskers were formed subglacially. They must also be younger than the drumlins. The eskers, although striking features, are very much subordinate in size to the drumlins. However, they are often found in sinuous channels, the formation of which involved erosion and truncation of drumlins (Fig. 11). In several cases, eskers extend from one side of a channel to the other. An example is to be seen in the large channel which trends northeast-south-west on Figure 11. The width of this channel is about $1 \mathrm{~km}$ and similar channels are widespread. The sinuous nature of the channels suggests a fluvial origin. Erosion of the drumlins during channel formation illustrates that the channels are younger than the drumlins, but the preservation of eskers which extend across these channels shows that they are older than the eskers. Both the drumlins and the eskers are subglacial forms related to the same ice sheet. It follows that the large channels were also cut subglacially. Note also the large crescentic scour on Figure 11 which is found up-stream of a large drumlin. These scours are common in the area. They are best explained as crescentic scours formed at the leading edge of an obstacle submerged in a flow (Karcz, 1968). Lundqvist (1970, p. 322) noted similar scours in a drumlin tract in Sweden. He likened these to erosional marks or Sichelwannen described by Dahl (1967) 


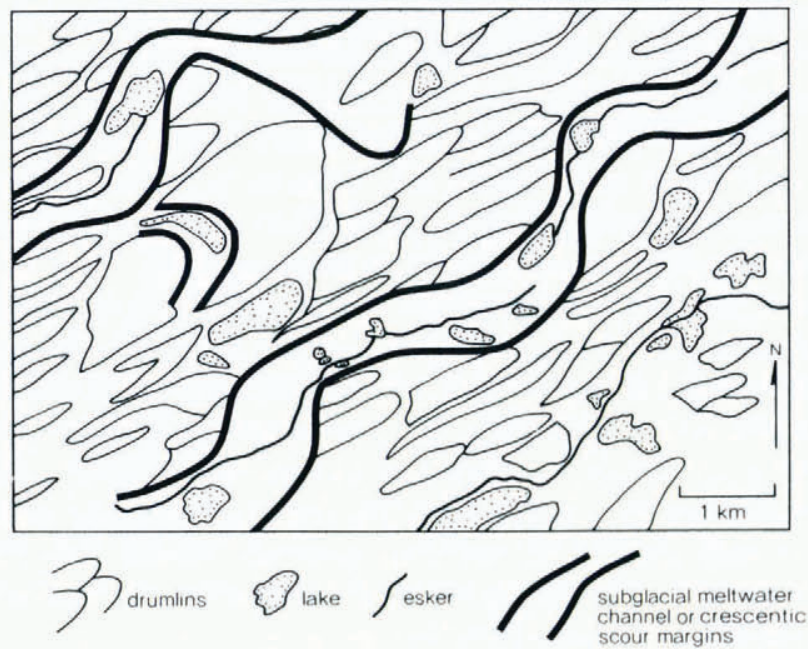

Fig. 11. Drumlins, eskers, and large-scale features of melt-water erosion. Drawn from air photograph A 14509-3. The centre of the photograph is located at approximately map reference 500860, Snare Lake Saskatchewan 1: 50000 NTS Map Sheet $74 \mathrm{~J} / 5$.

and wrote, "most probably they were formed as some kind of negative drumlin". This accords with the ideas presented here, but with erosion by water rather than ice as suggested by Lundqvist (1970). Both the channels and crescentic scours attest to the involvement of subglacial water flow in the formation of landforms which were created after the drumlins, but are on approximately the same scale as them. The increase in linear scale of flows which produced the eskers to that required to produce the channels and crescentic scours is thus much greater than the scale increase from the channels and scours to drumlins. Consequently, it is reasonable to propose that the drumlins were formed as a result of erosion by subglacial melt water. Wright (1973, fig. 2) described a similar arrangement of drumlins, tunnel valleys, and eskers in Minnesota. However, he interpreted the drumlins in a more conventional way.

\section{STRATIFIED DEPOSITS IN DRUMLINS}

Sorted and stratified deposits are widely reported to occur in drumlins and large-scale flutings (Upham, 1894; Alden, 1905; Slater, 1929; Gravenor, 1953; Lemke, 1958; Hoppe, 1963; Johansson, 1972; Bayrock, 1972; Shaw and Freschauf, 1973; Muller, [ $\left.{ }^{\mathrm{c}} 1974\right]$; Gillberg, 1976; Whittecar and Mickelson, 1979; Dardis 1982). If the environment and processes of deposition for this stratified material can be determined then we might make some progress on the question of drumlin genesis. Analysis of the internal structure of a drumlin near Camden East, south-east Ontario, Canada, demonstrates this approach. The drumlin is situated in the extreme northeastern part of the Belleville drumlin field (Chapman and Putman, 1972) and has been quarried for fill. It stands on a broad interfluve, and Paleozoic limestone lies at or very close to the ground surface in the immediate vicinity.

A broad stratigraphy within the drumlin is conformable with the landform surface. The lower parts of the exposed sections are dominated by undisturbed stratified sediments interbedded with 
thin diamicton units (Fig. 12). A variety of stratification and erosional features illustrates the work of running water. Paleocurrent estimates from cross-bedding and cross-lamination show flow directions to have been dispersed about the drumlin axis (Fig. 12). Diamicton is dominant towards the tops of sections 2 and 3 but thin sand beds are found even there. Striated and faceted clasts of Paleozoic and Shield rocks which are common in the diamictons illustrate a glacial derivation. In addition, incorporated blocks derived from the underlying sands and gravels are found particularly towards the bases of the thicker diamicton units.

The implications of the above observations for drumlin genesis will now be considered. The interstratified thin diamicton beds and sorted sediments, together with the clasts of sand and gravel within the diamictons, do not support the interpretation that this drumlin is composed mainly of lodgement till. At the same time, the situation of the drumlin on an interfluve speaks against accumulation of the stratified sediment on a broad outwash plain, as does the conformity between the stratigraphy and the drumlin form. The undisturbed nature of much of the stratified sediment and the virtual absence of surficial materials around the drumlin illustrate the unlikelihood that it formed by the subglacial deformation processes outlined by Wilson (1938), Smalley and Unwin (1968), and Boulton (1979).

We must follow the conclusion of Muller ([c 1974$])$ that stratified sediment with the characteristics described accumulated as an integral part of drumlin formation. Deposition in a subglacial cavity, with sedimentation processes similar to those described for the formation of "lee-side" till (Hillefors, 1973), best explains this accumulation. Lemke (1958) also described intercalation of thin diamicton and sand beds in drumlins. He considered the possibility of deposition in a cavity but rejected it because of the difficulty of explaining the origin of the cavity. Other researchers also considered the formation of drumlins in cavities (Stalker, 1960; Menzies, 1979), and the above explanation of the Camden East drumlin requires one. The

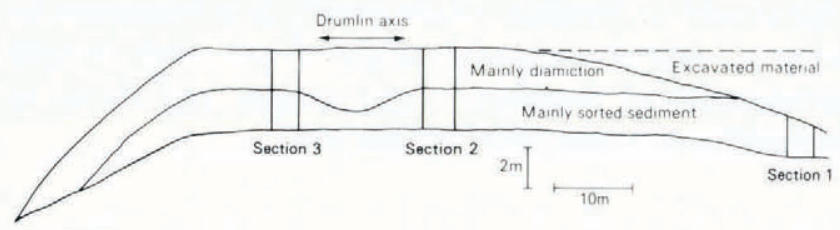

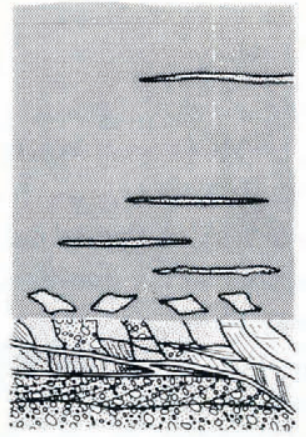

Section 3

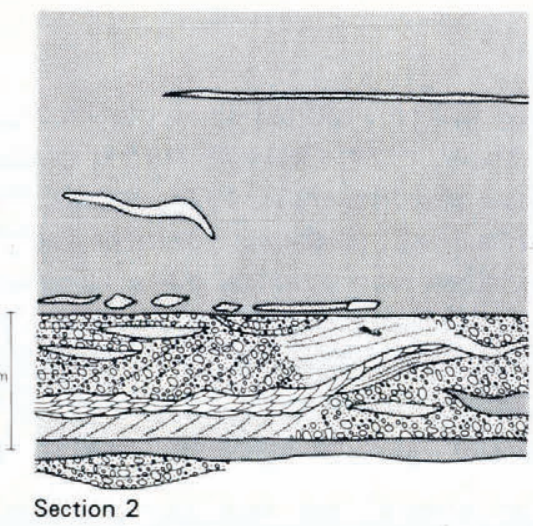

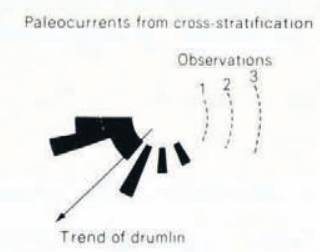

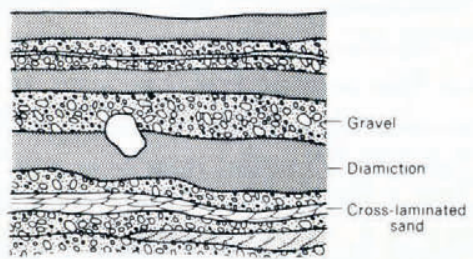

Section 1

Fig. 12. Internal structure and palaeocurrents, Camden East drumlin. 
erosional-mark hypothesis is attractive as it explains both the formation of a cavity and the depositional sequence in some drumlins.

\section{GLACIOTECTONIC STRUCTURES WITHIN DRUMLINS}

Stratified sediments and associated diamictons do not always show an intact primary stratigraphy (Alden, 1905; Eberl, 1930, cited in Menzies, 1979; Muller, [ ${ }^{\mathrm{c}} 1974$ ]; Whittecar and Mickelson, 1979; Gambier in Proudfoot and others, 1982, fig. 29). At least in the case presented by Gambier, thrusting post-dated the formation of the drumlin ridge, and must be seen as a consequence rather than a cause of drumlin formation. Whittecar and Mickelson (1979) summarized their observations on the deformation within drumlins in a diagram (Fig. 13). They concluded (p. 369), "Whatever the features shown, however, they often indicate that material was being moved into the drumlin from below." Similar lateral and vertical movement is illustrated by the "herring-bone" fabrics of drumlin tills (Gravenor and Menley, 1958; Evenson,

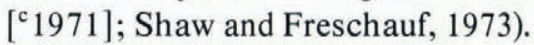

The erosional-mark hypothesis explains the thrusting on the stoss side of drumlins (Eberl, 1930; Muller, [ ${ }^{\mathrm{C}}$ 1974]; Gambier in Proudfoot and others, 1982) as a result of glacier flow against the up-stream side of a drumlin subsequent to its primary formation by cavity fill. If the glacier or ice sheet were resting on the bed around a cavity, a fall in subglacial water pressure would cause the cavity to become a region of relatively low pressure. Lateral and upwards movement into the cavity of deformable materials is then expected. This explains the deformation structures (Fig. 13).
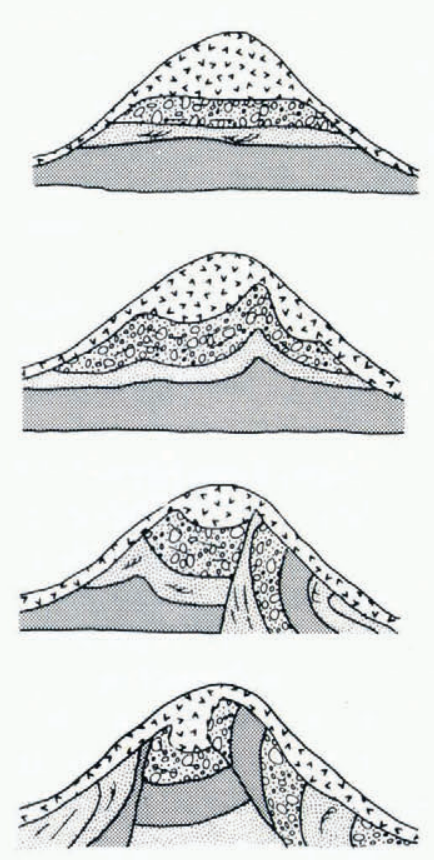

Fig. 13. Idealized range of structures found within the Waukesha-area drumlins. Included in these sketches are clastic dykes, high-angled faults, large overturned folds, and highly complex combinations of these features. Two tills are shown, the heavily stipled one represents the "advance" till of Whittecar and Mickelson (1979) and the surface till with triangular symbols represents their "retreat" till. All stratigraphic symbols are diagramatic. These diagrams and this caption follow closely Whittecar and Mickelson (1979). 


\section{CONCLUSIONS AND IMPLICATIONS}

It has been said that there are almost as many theories of drumlin formation as there are drumlins. This plethora of theories is not surprising, as the large drumlins and drumlin fields discussed here were formed under thick ice and at a considerable distance behind the ice marginal position at the time of formation. All theories are based on assumptions in the absence of direct observations. The founding assumption of most drumlin theories is that form represents a response to stresses exerted by flowing ice, and it is usually considered that this is an equilibrium form. The Athabasca Plains drumlins are shaped differently from what would be expected had the equilibrium conditions outlined by Chorley (1959) ensued during their formation. The plan view of their rims, rather than being blunt and broadly rounded in the proximal portion, is sharply pointed. In striking contrast with the gradually tapered tails of classical drumlins, the parabolic forms of the Athabasca Plains are widest close to their distal extremities. In this paper, an analogy has been drawn, on the basis of form, between drumlins and erosional marks produced by separated flows. It is ironic that in Chorley's explanation drumlins are created in a manner which prevents flow separation, whereas here they are related to the very presence of separated flows. That two fundamentally opposed hypotheses can stand, indicates the primitive level of our understanding of drumlin formation. It points particularly to the absence of stringent tests for the various hypotheses. Without such tests, a number of hypotheses remain plausible, and, even if stringent tests were available, it may be that there are several drumlin-forming mechanisms. Although the erosional-mark hypothesis explains many drumlin characteristics, it would be rash at this stage to suggest that it describes the only, or even the most powerful mechanism of drumlin formation.

The erosional-mark hypothesis evolved from the close form analogy between drumlins and casts of erosional marks and the analogy of form assemblages. The relative heights of parabolic and spindle-shaped drumlins is as predicted by the analogy, with parabolic forms being higher and representing unstable features and the lower, spindle forms representing stable features (Allen, 1971). The flow requirements for the formation of large-scale erosional marks on an ice bed are reasonable in view of the sources of melt water and the potential for melt-water storage and release in the ice-sheet system. Large-scale subglacial melt-water channels succeeded drumlin formation in the Saskatchewan field with the subsequent formation of eskers. In the erosional-mark hypothesis, this represents a predictable sequence of events with large-scale sheet water flow becoming concentrated into narrower conduits that involved erosion of both ice and the substrate. In the final stage, erosion was confined to the ice and deposition on the bed created eskers in relatively small conduits. The internal composition, structure, and stratigraphy of many drumlins can be explained by the erosional-mark hypothesis which requires a cavity, but are not easily accounted for in other hypotheses of drumlin formation.

Should the erosional-mark origin for drumlins be true then it has implications beyond the mechanics of drumlin formation. If part of a glacier or ice sheet is supported, even temporarily, on an extensive sheet of water, it is lifted clear of many of the obstacles that carry the basal shear stress. Without this basal resistance the glacier will tend to accelerate and some of the tangential stress that was carried by the now partially floating bed must be applied elsewhere. High stress concentrations are expected at the lateral margins of the floating zone and at its leading edge. The widespread thrusting often associated with drumlins (Moran and others, 1980; Jones, 1982) might be related to these stress concentrations. Given the non-linear behaviour of ice, these zones of stress concentration are expected to be zones with high rates of strain. An eventual flattening of the profile is expected and a flat profile for the Laurentide ice sheet has been proposed on 
geomorphological and geophysical grounds (Mathews, 1974; Andrews, 1973, 1982). This also has implications for the problematically high rates of retreat of this ice sheet (Andrews, 1982). In addition, high subglacial discharges of melt water are required to explain the details of interbedded till and stratified sediment on the Prairies (Shaw, 1982) and were also a major factor in the formation of large subaqueous, ice-marginal fans in glacial lakes (Rust and Romanelli, [ ${ }^{\mathrm{c}}$ 1975]; Shaw, [ ${ }^{\mathrm{c}}$ 1975]). Finally, the mechanism of drumlin formation by melt water may be considered part of a sequence in which drumlin formation is followed by the erosion of tunnel valleys which are in turn followed by the deposition of eskers.

\section{ACKNOWLEDGEMENTS}

Thirteen years after leaving Reading, I thought I had escaped the influence of Professor John Allen, but it evidently remains strong. Dr Jack Mollard drew my attention to the Athabasca Plains drumlins through their appearance on Landsat imagery. Peter Ashmore, Lee Clayton, George Dardis, Robert Gilbert, and John Menzies made helpful comments on a draft of this paper. Inge Wilson, Michael Fisher, and Ross Hough drafted the figures. Carolyn King did some of the map analysis. Research was supported by National Research Council of Canada grant A 7831 .

MS. received 14 December 1982 and in revised form 20 April 1983

\section{REFERENCES}

Acton, D. F., and others. 1960. Physiographic divisions of Saskatchewan, [by] D. F. Acton, J. S. Clayton, J. G. Ellis, E. A. Christiansen, W. O. Kupsch. [Regina], Saskatchewan Soil Survey in co-operation with Geology Division, Saskatchewan Research Council, and Geology Dept., University of Saskatchewan. [Map. Scale 1:1 520640.$]$

Alden, W. C. 1905. The drumlins of southeastern Wisconsin. U.S. Geological Survey. Bulletin 273, p. 9-46.

Alden, W. C. 1918. The Quaternary geology of southeastern Wisconsin. U.S. Geological Suvey. Professional Paper 106.

Allen, J. R. L. 1971. Transverse erosional marks of mud and rock: their physical basis and geological significance. Sedimentary Geology, Vol. 5, Special Issue Nos. 3-4, p. 167-385.

Andrews, J. T. 1973. The Wisconsin Laurentide ice sheet: dispersal centers, problems of rates of retreat, and climatic implications. Arctic and Alpine Research, Vol. 5, No. 3, Pt. 1, p. 185-99.

Andrews, J. T. 1982. On the reconstruction of Pleistocene ice sheets: a review. Quaternary Science Reviews, Vol. 1, No. 1, p. 1-30.

Bayrock, L. A. 1972. Surficial geology, Fort Chipewyan. Alberta. Research Council. [Map], NTS 74L. [Scale $1: 250000$.

Blake, D. A. W. 1956. Geological notes on the region south of Lake Athabasca and Black Lake, Saskatchewan and Alberta. Canada. Geological Survey. Paper 55-33.

Boulton, G. S. 1979. Processes of glacier erosion on different substrata. Journal of Glaciology, Vol. 23, No. 89, p. $15-38$.

Chapman, L. J., and Putnam, D. F. 1972. Physiography of the eastern portion of southern Ontario. Ontario. Dept. of Mines and Northern Affairs [and] Ontario Research Foundation, Map 2227. [Scale 1:253 440.]

Chorley, R. J. 1959. The shape of drumlins. Journal of Glaciology, Vol. 3, No. 25, p. 339-44.

Christiansen, E. A. 1979. The Wisconsinan deglaciation of southern Saskatchewan and adjacent areas. Canadian Journal of Earth Sciences, Vol. 16, No. 4, p. 913-38.

Dahl, R. 1967. Senglaciala akkumulationsformer och glaciationsförhảllanden i Narvik-Skjomenområdet, Norge. Norsk Geografisk Tidsskrift, Bd. 21, Ht. 3, p. 157-241. 
Dardis, G. F. 1982. Till facies associations in drumlins and some implications to their mode of formation. Eleventh International Congress on Sedimentology, McMaster University, Hamilton, Ontario, Canada, August 22-27, 1982. Abstracts of Papers, p. 78.

Dzulinski, S., and Walton, E. K. 1965. Sedimentary features of flysch and graywackes. Amsterdam, Elsevier.

Eberl, B. 1930. Die Eiszeitenfolge im nördlichen Alpenvorlande. Augsburg, B. Filser.

Evenson, E. B. [ $\left.{ }^{c} 1971.\right]$ The relationship of macro- and micro-fabrics in till and the genesis of glacial landforms in Jefferson County, Wisconsin. (In Goldthwait, R. P., ed. Till: a symposium. [Columbus], Ohio, Ohio State University Press, p. 345-64.)

Gillberg, G. 1976. Drumlins in southern Sweden. Bulletin of the Geological Institutions of the University of Uppsala, New Series, Vol. 6, p. 125-89.

Glückert, G. 1973. Two large drumlin fields in central Finland. Fennia, 120.

Gravenor, C. P. 1953. The origin of drumlins. American Journal of Science, Vol. 251, No. 9, p. 674-81.

Gravenor, C. P., and Menley, W. A. 1958. Glacial flutings in central and northern Alberta. American Journal of Science, Vol. 256, No. 10, p. 715-28.

Hillefors, A. 1973. The stratigraphy and genesis of stoss- and lee-side moraines. Bulletin of the Geological Institutions of the University of Uppsala, New Series, Vol. 5, p. 139-54.

Hoppe, G. 1963. Subglacial sedimentation, with examples from northern Sweden. Geografiska Annaler, Vol. 45, No. 1, p. 41-51.

Johansson, H. G. 1972. Moraine ridges and till stratigraphy in Västerbotten, northern Sweden. Sveriges Geologiska Undersökning, Avhandlingar och Uppsatser, Ser. C, Nr. 673, Arsbok 66, Nr. 4.

Jones, N. 1982. The formation of glacial flutings in east-central Alberta. (In Davidson-Arnott, R., and others ed. Research in glacial, glacio-fluvial, and glacio-lacustrine systems: proceedings of the 6th Guelph symposium on geomorphology, 1980. Edited by R. Davidson-Arnott, W. Nickling, B. D. Fahey. Norwich, Geo Books in association with Geomorphology Symposium, University of Guelph, p. 49-70. (Dept. of Geography, University of Guelph. Geographical Publication No. 6.))

Karcz, I. 1968. Fluvial obstacle marks from the wadis of the Negev (southern Israel). Journal of Sedimentary Petrology, Vol. 38, No. 3, p. 1000-12.

Lemke, R. W. 1958. Narrow linear drumlins near Velva, North Dakota. American Journal of Science, Vol. 256, No. 4, p. $270-83$.

Lundqvist, J. 1970. Studies of drumlin tracts in central Sweden. Acta Geographica Lodziensia, No. 24, p. $317-26$.

Mathews, W. H. 1974. Surface profiles of the Laurentide ice sheet in its marginal areas. Journal of Glaciology, Vol. 13, No. 67, p. $37-43$.

Menzies, J. 1979. A review of the literature on the formation and location of drumlins. Earth-Science Reviews, Vol. 14, No. 4, p. 315-59.

Moran, S. R., and others. 1980. Glacier-bed landforms of the prairie region of North America, by S. R. Moran, L. Clayton, R. L. Hooke, M. M. Fenton, and L. D. Andriashek. Journal of Glaciology, Vol. 25, No. 93, p. 457-76.

Muller, E. H. [ $\left.{ }^{c} 1974.\right]$ Origins of drumlins. (In Coates, D. R., ed. Glacial geomorphology. Binghamton, New York, State University of New York, p. 187-204. (Publications in Geomorphology.))

Prest, V. K., and others. 1968. Glacial map of Canada, by V. K. Prest, D. R. Grant, and V. N. Rampton. Canada. Geological Survey. [Map] 1253 A. [Scale 1:5 000 000.]

Proudfoot, D. N., and others. 1982. Excursions 20B: Glacial and postglacial sediments Edmonton-Jasper-BanffCalgary area, Alberta, A ugust 29th to September 2, 1982. By D. N. Proudfoot, R. W. May, N. W. Rutter, J. Shaw. Eleventh International Congress on Sedimentology. Field excursion guide book. [Edmonton, International Association of Sedimentologists.]

Rose, J., and Letzer, J. M. 1977. Superimposed drumlins. Journal of Glaciology, Vol. 18, No. 80, p. 471-80.

Rust, B. R., and Romanelli, R. [ $\left.{ }^{\mathrm{C}} 1975.\right]$ Late Quaternary subaqueous outwash deposits near Ottawa, Canada. (In Jopling, A. V., and McDonald, B. C., ed. Glaciofluvial and glaciolacustrine sedimentation. Tulsa, Oklahoma, Society of Economic Paleontologists and Mineralogists, p. 177-92. (Special Publication No. 23.))

Shaw, J. [ $\left.{ }^{\mathrm{C}} 1975.\right]$ Sedimentary successions in Pleistocene ice-marginal lakes. (In Jopling, A. V., and McDonald, B. C., ed. Glaciofluvial and glaciolacustrine sedimentation. Tulsa, Oklahoma, Society of Economic Paleontologists and Mineralogists, p. 281-303. (Special Publication No. 23.))

Shaw, J. 1982. Melt-out till in the Edmonton area, Alberta, Canada. Canadian Journal of Earth Sciences. Vol. 19, No. 8, p. 1548-69.

Shaw, J., and Freschauf, R. C. 1973. A kinematic discussion of the formation of glacial flutings. Canadian Geographer, Vol. 17, No. 1, p. 19-35. 
Slater, G. 1929. Structure of drumlins on southern shore of Lake Ontario: N. Y. State. Bulletin of the New York State Museum, No. 281, p. 3-19.

Smalley, I. J., and Unwin, D. J. 1968. The formation and shape of drumlins and their distribution and orientation in drumlin fields. Journal of Glaciology, Vol. 7, No. 51, p. 377-90.

Sproule, J. C. 1939. The Pleistocene geology of the Cree Lake region, Saskatchewan. Transactions of the Royal Society of Canada, Sect. 4, Vol. 33, p. 101-09.

Stalker, A. 1960. Ice-pressed drift forms and associated deposits in Alberta. Canada. Geological Survey. Bulletin 57, p. 1-38.

Upham, W. 1894. The Madison type of drumlins. American Geologist, Vol. 14, No. 2, p. 69-83.

Whittecar, G. R., and Mickelson, D. M. 1979. Composition, internal structures, and an hypothesis of formation for drumlins, Waukesha County, Wisconsin, U.S.A. Journal of Glaciology, Vol. 22, No. 87, p. 357-71.

Wilson, J. T. 1938. Drumlins of south-west Nova Scotia. Transactions of the Royal Society of Canada, Sect. 4, Vol. 32, p. 516-24.

Wright, H. E., jr. 1973. Tunnel valleys, glacial surges, and subglacial hydrology of the Superior Lobe, Minnesota. (In Black, R. F., and others, ed. The Wisconsinan Stage. Edited by R. F. Black, R. P. Goldthwait, H. B. Willman. Boulder, Colorado, Geological Society of America, Inc., p. 251-76. (Geological Society of America. Memoir 136.)) 